\title{
GANGGUAN TINGKAH LAKU PADA ANAK
}

\author{
Rehani \\ Dosen Fakultas Tarbiyah IAIN Imam Bonjol Padang \\ e-mail: rehani_15@yahoo.co.id
}

\begin{abstract}
Mental disorder is a repetitive and persistent pattern that violated human's rignt and social norms. There are some type of mental disorder such as aggression to people and animal, destruction of property, deceitfulness or theft and serious violations of rules, and other serious violations of rules.

Abstrak: Gangguan tingkah laku adalah pola perilaku yang tetap yang melanggar hak-hak dasar orang lain dan norma susila. Ada beberapa kriteria gangguan tingkah laku yaitu agresi terhadap orang lain dan hewan,menghancurkan kepemilikan, berbohong atau mencuri dan pelanggaran aturan yang serius, melakukan penipuan atau pencurian, dan melakukan pelanggaran aturan yang serius
\end{abstract}

Kata Kunci: Gangguan, tingkah laku

\section{PENGERTIAN GANGgUAN TINGKAH LAKU}

Dalam DSM-IV-TR didefinisikan bahwa gangguan tingkah laku atau conduct disorder adalah pola perilaku yang tetap yang melanggar hak-hak dasar orang lain dan norma susila. conduct disorder as a repetitive and persistent pattern of behavior in which either the rights of ithers or major age appoptiate societal norms or ruler violated (Charles Wenar dan Patricia Kerig, t.t: 297). Dalam bukunya Tingkah Laku Abnormal, Linda De Clerg mengemukakan bahwa istilah gangguan tingkah laku atau conduct disorder mengacu pada pola perilaku antisosial yang bertahan yang melanggar hakhak orang lain dan norma susila.(Linda De Clerg, 1994: 167).

Charles Wenar dan Patricia Kerig dalam bukunya Development Psychopathology from Infancy Though Adolescence mengemukakan bahwa kriteria conduct disorder dalam DSMIV-TR yaitu aggression to people and animal (agresi terhadap orang lain dan hewan), destruction of property (menghancurkan kepemilikan), deceitfulness or theft (berbohong atau mencuri) and serious violations of rules (pelanggaran aturan yang serius).( Charles Wenar dan Patricia Kerig, t.t, 298). American Psychiatric Association, mengemukakan beberapa kriteria conduct disorder dari masingmasing kategori conduct disorder sebagai berikut: Pertama, conduct disorder merupakan pola prilaku yang repetitive dan persisten yang ditandai oleh adanya pelanggaran hak-hak dasar. Setidaknya 3 dari hal-hal berikut muncul dalam 12 bulan terakhir, seperti : aggression to people and animals (agresi terhadap orang dan hewan), misalnya: (1) sering melakukan bully, ancaman, mengintimidasi orang lain, (2) sering memulai petengkaran fisik, (3) menggunakan senjata yang dapat menyebabkan bahaya fisik terhadap orang lain (misalnya tongkat, botol pecah, pisau, pistol), (4) melakukan kekejamna fisik terhadap orang lain, (5) melakukan kekejaman fisik terhadap hewan, (6) mencuri sambil mengkonfrontasi korban (misalnya pencopetan, perampokan bersenjata), (7) me-maksa seseorang untuk melakukan aktivitas seksual, atau destruction of property (mela-kukan pengrusakan barang), misalnya: (8) mela-kukan pembakaran secara sengaja dengan tujuan untuk menghasilkan kerusakan yang serius, (9) melakukan pengrusakan barang atau benda secara sengaja. Atau deceitfulness or theft (melakukan penipuan atau pencurian), misalnya: (10) masuk secara paksa ke dalam rumah, bnagunan atau mobil, (11) sering berbohong untuk memperoleh barang atau jasa atau untuk menghindari kewajiban (misalnya mengutil namun tanpa merusak), (12) mencuri tanpa konfrontasi. Atau serious violations of rules (melakukan pelanggaran aturan yang serius), 
misalnya: (13) sering keluar rumah pada malam hari meskipun dilarang, yang dimulai pada usia 13 tahun, (14) melarikan diri dari rumah pada malam ahri setidaknya 2 kali selama tinggal di rumah orang tua atau orang tua asuh (atau satu kali tanpa kembali ke rumah untuk janga waktu lama), (15) sering bolos dari sekolah yang di mulai sebelum usia 13 tahun. (American Psychiatric Association, 2000: 98).

Kedua, gangguan perilaku tersebut menyebabkan kerusakan yang segnifikan pada fungsi sosial, akademis atau pekerjaan. Dan ketiga, apabila individu berusia 18 tahun atau lebih maka kriteria yang ditampilkan bukan kriteria Conduct Disorder tetapi Antisocial Personality Disorder.

Berdasarkan awal munculnya gangguan tingkah laku atau conduct disorder dapat di bagi menjadi tiga, yaitu : conduct disorder, childhood-onset type : kemunculan sekurangnya satu kriteria dari karakteristik conduct disorder $s$ sebelum usia 10 tahun. Kedua, conduct disorder, adolescent-onset type : karakteristik conduct disorder tidak ada yang ditampilkan sebelum usia 10 tahun. Ketiga, conduct disorder unspecified onset, usia kemunculan tidak diketahui. (American Psychiatric Association, 2000: 95).

Berdasarkan tingkat keparahan maka conduct disorder dapat dispesifikasi sebagai berikut: Pertama, mild: masalah perilaku hanya sedikit melewati kriteria yang disyaratkan (kalau ada) dan masalah perilaku hanya menyebabkan bahaya ringan terhadap orang lain. Kedua, moderate: jumlah dan dampak masalah perilaku yang di tampilkan berada antara "mild" dan "severe". Ketiga, severe: masalah perilaku banyak yang melewati kriteria yang disyaratkan atau masalah perilaku menyebabkan bahaya yang besar terhadap orang lain.(American Psychiatric Association, 2000: 98). American Psychiatric Association menje-laskan bahwa conduct disorder terutama jenis childhood-onset type, lebih banyak dimiliki oleh laki-laki daripada perempuan. Perbedaan jender juga mempengaruhi jenis masalah conduct yang ditampilkan. Laki-laki dengan diagnosis conduct disorder seringkali menampilkan perilaku bertengkar, mencuri, vadalisme dna pelanggaran disiplin sekolah. Sednagkan perempuan dengan diagnosis conduct disorder seringkali menampilkan perilaku berbohong, bolos, melarikan diri daari rumah, menggunakan obat terlarang dan prostitusi. Perilaku konfrontatif lebih banyak digunakan oleh lakilaki daripada perempuan.

\section{FAKTOR PENYEBAB CONDUCT DISOR- DER}

Menurut Ernar dan Kerig, faktor-faktor yang menyebabkan conduct disorder dapat dibedakan menjadi faktor biologis, faktor individual dan faktor keluarga.

\section{a. Faktor Biologis}

Wenar dan Kerig menyatakan temperamen merupakan penyebab biologis bagi terbentuknya conduct disorder. Sebagai contoh Moffit dan Lyman dalam Wenar dan Kerig mengatakan bahwa hal yang mem pengaruhi berkembangnya perilaku yaitu adanya disfungsi neuropsikologis yang berhubungan dengan temperamen sulit yang memicu munculnya impulsivitas, perasaan mudah tersinggung dna aktivitas berlebihan pada anak. (Charles Wenar dan Patricia Kerig, t.t: 314-320).

Temperamen yaitu gaya karakteristik seseorang dalam melakukanm pendekatan dan bereaksi terhadap orang dan situasi dilingkungannya. (Diane E. Papalia dan Sally Wendkos, 1995: 171). Temperamen dapat diartikan sebagai cara (bagaimana) seseorang melakukan suatu hal. Menurut Izard dalam Diane E. Papalia dan Sally Wendkos Olds, bayi berusia 8 minggu telah menunjukkan tandatanda perbedaan temperamen yang membentuk bagian penting dari kepribadiannya. A. Thomas, Chess dan Birch dalam Diane E. Papalia dan Sally Wendkos Olds mengidentifikasikan sembilan komponen temperamen yang muncul pada bayi setelah dilahirkan, yaitu (1) level aktivitas: bagaimana dan seberapa banyak individu bergerak, (2) Ritme atau keteraturan: sejauh mana suatu siklus biologis dapat dipresiksi, seperti rasa lapar, waktu tidur dan buang air, (3) Respons mendekat (approach) atau menjauh (withdrawal): bagaimana individu awalnya berespons terhadap stimulus baru, seperti mainan, makanan atau orang baru, (4) Adaptabilitas: seberapa mudah suatu respon awal dimodifikasi sesuai dengan situasi yang 
baru atau situasi yang berubah, (5) Ambang responsivitas: berapa banyak stimulasi yang dibutuhkan untuk menghasilkan suatu respon, (6) Intensitas reaksi : seberapa energik individu dalam merespon, (7) Kualitas suasana hati (mood): apakah individu menampilkan mayoritas perilaku yang menyenangkan, gembira dna bersahabat atau kebalikannya, (8) Distraktibilitas: sejauh mana suatu stimulus yang relevan dapat mengubah atau menganggu perilaku indivisu, (9) Rentang perhatian dna persistensi: berapa lama individu melakukan suatu aktivitas dan tetap melanjutkannya walaupun terdapat hambatan.

Berdasarkan sembilan komponen temperamen tersebut, para peneliti menetapkan tiga pola temperamen yaitu temperamen mudah (easy), sulit (difficult), dan lambat (slow-to-warm-up). Penjelasan mengenai setiap pola temperamen tersebut dalam table berikut:

\begin{tabular}{|c|c|c|}
\hline Easu Child & $\begin{array}{l}\text { Difficult } \\
\text { Child }\end{array}$ & $\begin{array}{l}\text { Slow-to-Warm- } \\
\text { Up Child }\end{array}$ \\
\hline $\begin{array}{l}\text { Berespon } \\
\text { secara baik } \\
\text { terhadap situasi } \\
\text { yang baru/ } \\
\text { situasi yang } \\
\text { berubah }\end{array}$ & $\begin{array}{l}\text { Berespon } \\
\text { secara buruk } \\
\text { terhadap } \\
\text { situasi yang } \\
\text { baru / situasi } \\
\text { yang breubah }\end{array}$ & $\begin{array}{l}\text { Berespon secara } \\
\text { lambat terhadap } \\
\text { situasi yang } \\
\text { baru / situasi } \\
\text { yang breubah }\end{array}$ \\
\hline $\begin{array}{l}\text { Cepat } \\
\text { mengembang } \\
\text { kan pola / } \\
\text { jadwal tisur } \\
\text { dan makan } \\
\text { yang teratur }\end{array}$ & $\begin{array}{l}\text { Memiliki } \\
\text { jadwal tisur } \\
\text { dan makan } \\
\text { yang tidak } \\
\text { teratur }\end{array}$ & $\begin{array}{l}\text { Pola tisur dan } \\
\text { makan lebih } \\
\text { teratur daripada } \\
\text { anak } \\
\text { bertemperamen } \\
\text { sulit namun } \\
\text { lebih tidak } \\
\text { teratur } \\
\text { dibandingkan } \\
\text { anak yang } \\
\text { bertemperamen } \\
\text { mudah }\end{array}$ \\
\hline $\begin{array}{l}\text { Mudah } \\
\text { mengkonsumsi } \\
\text { jenis makanan } \\
\text { baru }\end{array}$ & $\begin{array}{l}\text { Lambat } \\
\text { menerima } \\
\text { jenis } \\
\text { makanan baru }\end{array}$ & $\begin{array}{l}\text { Menunjukkan } \\
\text { respon awal } \\
\text { yang sedikit } \\
\text { negative } \\
\text { terhadap } \\
\text { stimulus baru }\end{array}$ \\
\hline $\begin{array}{l}\text { Tersenyum } \\
\text { kepada orang } \\
\text { asing }\end{array}$ & $\begin{array}{l}\text { Curiga } \\
\text { terhadap } \\
\text { orang asing }\end{array}$ & \\
\hline $\begin{array}{l}\text { Mudah } \\
\text { beradaptasi } \\
\text { terhadap situasi }\end{array}$ & $\begin{array}{l}\text { Lambat } \\
\text { beradaptasi } \\
\text { terhadap }\end{array}$ & $\begin{array}{l}\text { Minat terhadap } \\
\text { stimulus baru } \\
\text { berkembang }\end{array}$ \\
\hline
\end{tabular}

\begin{tabular}{l|l|l}
\hline baru & situasi baru & $\begin{array}{l}\text { secara bertahap } \\
\text { setelah stimulus } \\
\text { diberikan } \\
\text { berulang kali } \\
\text { tanpa paksaan }\end{array}$ \\
\hline $\begin{array}{l}\text { Dapat } \\
\text { metoleran rasa } \\
\text { frustasi dengan } \\
\text { reaksi yang } \\
\text { tidak } \\
\text { berlebihan }\end{array}$ & $\begin{array}{l}\text { Bereaksi } \\
\text { tantrum } \\
\text { (mnegamuk) } \\
\text { terhadap rasa } \\
\text { frustasi }\end{array}$ & \\
\hline $\begin{array}{l}\text { Mudah } \\
\text { beradaptasi } \\
\text { terhadap } \\
\text { rutinitas baru } \\
\text { dan peraturan } \\
\text { permainan baru }\end{array}$ & $\begin{array}{l}\text { Lambat } \\
\text { beradaptasi } \\
\text { terhadap } \\
\text { rutinitas baru. } \\
\text { Sering } \\
\text { menangis dan } \\
\text { tertawa } \\
\text { dengan keras }\end{array}$ & \\
\hline $\begin{array}{l}\text { Umumnya } \\
\text { menampilkan } \\
\text { suasana hari } \\
\text { yang positif, } \\
\text { dengan } \\
\text { intensitas yang } \\
\text { ringan sampai } \\
\text { dengan sedang }\end{array}$ & $\begin{array}{l}\text { Umumnya } \\
\text { menampilkan } \\
\text { suasana hari } \\
\text { yang negative } \\
\text { secara } \\
\text { intensif }\end{array}$ & $\begin{array}{l}\text { Menampilkan } \\
\text { hati yang positif } \\
\text { maupun } \\
\text { negative dengan } \\
\text { intensitas ringan }\end{array}$ \\
\hline
\end{tabular}

Menurut A. Thomas dan Chess; Braungart, Plomin, DeFries dan Fulker; Emde dkk, bahwa temperamen mayoritas ditentukan oleh factor gereditas. Menurut A. Thomas dan Chess dalam Diane E. Papalia dan Sally Wendkos Olds, perbedaan individu dalam temperamen dasarnya tampaknya tidak diten-tukan oleh sikap orang tua atau oleh gender, urutan kelahiran atau kelas sosial. Namun menurut Person-Blennow dan Mc.Neil dalam Diane E. Papalia dan Sally Wendkos Olds, temperamen dapat berubah seiring berjalannya waktu. Hal itu ditunjukkan oleh penelitian yang dilakukan oleh New York Longitudinal Study (NYLS) pada tahun 1984 yang menemukan bahwa beberapa individu menunjukkan adanya perubahan temperamen walaupun sembilan aspek dasar temperamen yang mereka miliki tetap stabil. Tampaknya terkadang hal itu disebabkan oleh adanya kejadian/peristiwa yang dialami oleh individu atau adanya perbe-daan perilaku orang tua dalam menangani anak. (Diane E. Papalia dan Sally Wendkos, 1994: 172). 
Menurut Chess dan Thomas Wenar dan Patricia Kerig, karakteristik temperamen saja bukanlah faktor tunggal yang menentukan temperamen akhir individu. Hal itu dipengruhi oleh adanya kesesuaian antara temperamen adasr anak dana lingkungan sehingga menentukan apakah perkembangan anak menjadi sehat atau patologis. Anak akan mengalami stress apabila di tuntut untuk berperilaku yang berkebalikan dari temperamen dasarnya. Misalnya anak yang sangat aktif tinggal di rumah yang kecil dan diharapkan untuk duduk diam dalam jangka waktu lama; anak yang sloqto-warm-up dipaksa untuk menyesuaikan diri dengan banyak orang dan situasi baru. (Diane E. Papalia dan Sally Wendkos, 1994:173)

Selain itu genetic juga berperan dalam pembentukan masalah conduct pada anak walaupun peran lingkungan tidak dapat dikesampingkan. Selain itu, Charles Wenar dan Patricia Kerig memaparkan faktor biologis lainnya yang juga dapat berperan fslsm pembentukan gangguan tingkah laku pada anak yaitu adanya keracunan pada janin,a danya masalah psikofisiologis berupa rendahnya denyut jantung dna respons galvanic pada kulit sehingga anak mencari stimulasi melalui perilaku yang tidak terkontrol, adanya faktor biokimia atau hormon. (Charles Wenar dan Patricia Kerig, t.t: 314-315)

Para peneliti yang melakukan penelitian pada domain biologis menyatakan bahwa faktor organik tidak menyampingkan faktor sosial dan psikologis. Menurut Dodge dan Pettit faktor psikologis dan biologis saling mempengaruhi satu sama lain. (Charles Wenar dan Patricia Kerig, t.t:315)

\section{b. Faktor Individual}

Dalam Wenar dna Kerig, faktor individual yang berperan dalam pembentukan Conduct Disorder pada anak yaitu regulasi diri (selfregulation) yang kurang terbentuk sejak dini, regulasi emosi yang buruk sehingga anak tidak dapat mengembangkan strategi coping (strategi dalam mengatasi masalah) yang baik untuk mengatasi emosi negatifnya dan mengatur emosinya, kurang berkembangnya pemahaman moral dan empati, kognisi sosial anak yang berkembang dengan buruk, dan penggunaan obat-obatan terlarang. Berikutnya akan di jelaskan mengenai masing-masing faktor tersebut:

1)

\section{Regulasi Diri}

Regulasi diri merupakan hal yang penting agar seseorang dapat berfungsi secara normatif di lingkungannya. Harapan lingkungan terhadap kemampuan anak dalam mengntrol dorongan/ implus dalam dirinya semakin tinggi sesuai dengan bertambanhnya usia anak. Oleh karena itu, penanaman kontrol diri sejak usia dini merupakan hal yang penting karena anak usia balita danprasekolah memiliki dorongan yang tinggi untuk segera memuaskan dorongan agresif, seksual dna rasa ingin tahunya.(Charles Wenar dan Patricia Kerig, t.t: 315-317). Penelitian Hinshaw dan Lee dalam Charles Wenar dan Patricia Kerig menunjukkan bahwa anak-anak dengan conduct disorder memiliki kemampuan yang terbatas dalam menunda dorongan/implus dan mentoleransi rasa frustasi. (Charles Wenar dan Patricia Kerig, t.t, 316)

Anak-anak yang melaksanakan aturan/ perintah ibu dengan rela dan sepenuh hati bukan sekedar mematuhi semata, merupakan anakanak yang memiliki hubungan emosional timbal-balik yang positif dengan orang tuanya. Pola suh untuk menanamkan kontrol diri pada anak perlu disesuaikan dengan temperamen masing-masing anak. Anak bertemperamen sulit merupakan anak yang berisiko memiliki Conduct Disorder. Untuk meningkatkan regulasi diri pada anak bertemperamen sulit, dibutuhkan adanya peran orang tua yang besar untuk melibatkan diri dan memberikan dukungan emosional kepada anak.

\section{Regulasi Emosi}

Regulasi emosi merupakan bagian dari kontrol diri yang berperan bagi terbentuknya conduct disorder. (Charles Wenar dan Patricia Kerig, t.t: 320). Anak-anak dengan conduct disorder dalam kondisi keluarga yang bermasalah, mendapatkan pola asuh yang buruk, dan mengalami konflik tingkat tinggi sehingga mereka memiliki emosi yang kuat namun kurang mendapatkan dukungan untuk mengatasinya dari orang tua yang juga mengalami stress dan tidak terlatih. Oleh 
karenanya, mereka gagal mengembangkan strategi yang tepat untuk mengatasi emosi negative dan mengatur ekspresi mereka. Penelitian lainnya menunjukkan bahwa anak dengan conduct disorder mengalami kesulitan dalam mengatur emosinya, terutama kemarahan. Selian itu, anak dengan regulasi emosi yang buruk juga cenderung berespon secara agresif terhadap masalah interpersonal yang dihadapinya.

Selain kontrol emosi yang minim dapat mengarah kepada terbentuknya conduct disorder, kontrol emosi yang berlebihan juga dapat berdampak sama. Penelitian terhadap anak perempuan menunjukkan bahwa kontrol yang berlebihan terhadap emosinegatif yang membuat anak menaham amarahnya sekuat mungkin dapat menyebabkan emosi negatif tersebut terlampiaskan pada usia selanjutnya.

$\begin{array}{cl} & \text { Perkembangan Prososial } \\ \text { Menurut Piaget, pada saat anak }\end{array}$ memasuki usia sekolah dasar, anak mulai beranjak dari keadaan cognitive egocentrism (anak memandang dunia sekitar hanya dari sudut padangnya semata) kepada cognitive perspectivism (anak dapat memandang dunia dari sudut padang orang lain dengan mempertimbangkan hak dan perasaan orang lain). Perspective-taking yaitu kemampuan untuk melihat berbagai hal dari sudut padang orang lain, merupakan faktor penting bagi perkembangan penalaran moral dan empati. Penalaran moral dna empati dapat mencegah kecenderungan perilaku antisosial dan agresif.

\section{Kognisi Sosial}

Eron dan Huesmann dalam Charles

Wenar dan Patricia Kerig menyatakan bahwa perilaku agresif tidak semata ditentukan oleh adanya faktor pencetus di lingkungan namun kecendrungan agresif ada di dalam karakter individu. Selanjutnya Huesman dan Reynold agresif ada di dalam Charles Wenar dan Patricia Kerig menyatakan bahwa agresivitas berakar pada cognitive schemata yaitu kecendrungan untuk menginterprestasikan dan berespon terhadap kejadian; kecenderungan itu diperoleh dari pengalaman masa lalu dan digunakan untuk membimbing perilaku dimasa yang akan datang. (Charles Wenar dan Patricia Kerig, t.t:323)

Anak-anak dengan conduct disorder memiliki definisi dalam mengembangkan strategi untuk mengatasi masalah interpersonal. Selain itu anak-anak dengan conduct disorder juga memiliki cara yang berbeda dalam memproses informasi sosial. Mereka seringkali salah dalam menginterpretasikan niat/intensi orang lain di lingkungannya sehingga cenderung berespon secara implusif ataupun berlebihan. Mereka juga hanya memiliki sidikit alternatif dalam mengatasi masalah interpersonal dan mengharapkan hasil yang positif dari tindakan agresifnya.

Penggunaan Obat Terlarang

Penggunaan obat-obatan terlarang juga menyumbangn bagi terbentuknya perilaku kriminal yang serius. Hubungan antara Conduct Disorder dan penggunaan obat-obatan terlarang cenderung kompleks dan transaksional. Di satu sisi remaja yang tidak mampu mengatur perilaku dan emosi dapat merasa tertatik pada tantangan dan sensasi penggunaan obat terlarang. Apabila ia telah menyandu obat terlarang maka selanjutnya ia akan semakin sering terlibat dalam aktivitas illegal untuk mendapatkan obat terlarang dan menjadi bagian dari lingkungan yang antisosial. Selain itu, bahan yang terkandung dalam alkohol dan obat terlarang dapat memicu seseorang untuk terlibat dalam tindakan beresiko dan illegal.

\section{c. Faktor Keluarga}

Salah satu faktor yang paling berpengaruh dalam gangguan tingkah laku adalah pengaruh lingkungan kelaurga. Menurut Henggeler sebagaimana yang di kutip oleh Linda De Clerg, bahwa perilaku antisosial anak berhubungan dengan: (1) Perilaku antisosial orang tua mereka, (2) Strategi disiplin orang tua yang tidak efektif dan tidak konsisten serta lemahnya pengawasan orang tua (kurangnya teknik dan keterampilan), (3) Kurangnya komunikasi dan kasih sayang orang tua atau keluarga dan tingginya konflik keluarga.(Linda De Clerg, 1994:185).

Menurut Charles Wenar dan Patricia Kerig, factor keluarga yang mempengaruhi terben- 
tuknya Conduct Disorder adalah attachment (kelekatan orang tua dan anak), masalah dalam rumah tangga, psikopatologi yang dialami orang tua, pola asuh yang kasar dan penurunan perilaku agresif antar generasi, adanya teori coercion, dan proses transaksional dalam keluarga. Berikut penjelasan menganai masingmasing faktor:

1)

Attachment

Kelekatan (attachment) yang bersifat insecure antara orang tua dan anak ketika bayi mengarah bagi terbentuknya masalah perilaku pada saat anak berusia prasekolah, seperti berperilaku kasar dan melawan. Namun menurut Greenberg, Sprltz dan Deklyen dalam Charles Wenar dan Patricia Kerig, penelitian terakhir belum menemukan adanya dampak langsung dari attachment terhadap perilaku antisosial, walauoun hubungan yang buruk antara orang tua dan anak membawa resiko bagi perkembangan psikopatologi secara umum.

2)

\section{Tangga}

Menurut Shaw dkk dalam Charles Wenar dan Patricia Kerig, masalah yang terjadi dalam keluarga merupakan subur bagi terbentuknya perilaku antisosial untuk mencari perhatian lingkungan, terutama pada anak laki-laki. Menurut Graham-Bermann \& Edleson; Geffner dkk dalam Charles Wenar dan Patricia Kerig, anak-anak yang melihat atau mengalami kekerasan dalam rumah tangga akan berpotensi untuk mengembangkan masalah perilaku. Menurut Dodge, Petit dan Bates dalam Charles Wenar dan Patricia Kerig, anak juga seringkali menjadi target kekerasan orang tuanya, misalnya anak yang mengalami gangguan tingkah laku biasanya merupakan anak yang pernah mendapatkan perlakuan salah dari orangtuanya. Menurut Cummings dan Davies dalam Charles Wenar dan Patricia Kerig, gangguan tingkah laku juga berhubungan dengan konflik antar orang tua dan perceraian orang tua walaupun tidak disertai dengan kekerasan. Namun menurut McCord, bukan keadaan broken home sendiri yang menyebabkan masalah perilaku pada anak melainkan kualitas emosional yang ditampilkan antar angfota keluarga. Mislanya anak laki-laki jarang menjadi nakal walaupun hanya diasuh oleh ibu sebagai orang tua tunggal, selama ibu memiliki pola suh yang baik dan hubungan yang suportif dengan anak. (Charles Wenar dan Patricia Kerig, t.t:320-327).

Hal senada juga terungkap dari sebuah studi tentang para ibu bercerai yang depresif dan yang tidak depresif. Forgatch dan Patterson dalam Linda De Clerg menemukan bahwa para ibu yang depresif secara signifikan lebih mudah marah sehingga tidak efektif dalam menerapkan disiplin di bandingkan dengan ibu yang tidak depresif. Kemudian anak dari ibu yang depresif lebih agresif daripada anak-anak dari ibu yang tidak depresif. Studi ini memberi dukungan bagi hubungan antara deprsifnya ibu dan sikap mudah marahnya ibu dengan pemberian disiplin yang tidak efektif dan tingkah laku antisosial anak. Kelaurga dengan single parent juga beresiko terhadap perilaku conduct disorder pada anak. Figur seorang ayah juga sangat dibutuhkan oleh seorang anak. Seorang anak laki-laki tanpa adanya figur ayah akan beresiko terhadap perilaku conduct disorder. (Linda De Clerg, 1994: 190).

Kebanyakan dari anak yang agresif dari keluarga yang paling tidak salah satu dari orang tuanya kejam terhadap orang tuanya yang lain, kejam terhadap anak, terhadap saudarasaudaranya atau terhadap orang-orang lain di luar keluarganya. Kebanyakan anak-anak yang agresif ini mendapat penyiksaan baik secara fisik maupun emosional.

3)

Psikopatologi Orangtua

Orangtua pengguna obat-obatan terlarang, terutama ayah kemungkinan besar memicu Conduct Disorder pada anak. Menurut Cummings dan Davies dalam Charles Wenar dan Patricia Kerig, depresi yang dialami ibu juga berkaitan dengan masalah gangguan pada anak. Orangtua yang mengalami gangguan kepribadian antisosial juga meningkatkan kemungkinan muncul dan bertahannya gangguan tingkah laku pada anak.

4)

Pola asuh yang keras dan penurunan perilaku agresif antar generasi

Menurut Eron dan Huesmann dalam Charles Wenar dan Patricia Kerig, penelitian menunjukkan bahwa perilaku agresif tidak hanya diturunkan dalam satu generasi saja melainkan antar generasi sebelumnya juga dan 
perilaku agresif tersebut diturunkan melalui proses modeling (meniru), misalnya menirtu kekerasan yang dilakukan antar orangtua atau kekerasan yang dilakukan orangtua terhadap anak melalui hukuman yang kasar. (Charles Wenar dan Patricia Kerig,t.t: 319).

Seringkali orangtua merupakan model dalam sikap-sikap mereka menggunakan hukuman fisik dan emosional yang diterapkan dengan keras. Anak biasanya mengamati dan meniru perilaku agresif orang tuanya. Perilaku agresif anak juga disebabkan karena perilaku kriminal orang tua dan minuman alkohol. Di samping itu juga disebabkan karena adanya gangguan mental pada salah satu atau kedua orang tua. Depresi pada orang tua sangat erat kaitannya dengan masalah gangguan tingkah laku pada anak.

\section{SIMPULAN}

Gangguan tingkah laku atau conduct disorder mengacu pada pola perilaku antisosial yang bertahan yang melanggar hak-hak orang lain dan norma susila. Ada beberapa kriteria gangguan tingkah laku pada anak yang setidaknya 3 dari hal-hal berikut muncul dalam 12 bulan terakhir, seperti: agresi terhadap orang dan hewan misalnya: (1) sering melakukan bully, ancaman, mengintimidasi orang lain, (2) sering memulai petengkaran fisik, (3) menggu-nakan senjata yang dapat menyebabkan bahaya fisik terhadap orang lain (misalnya tongkat, botol pecah, pisau, pistol), (4) melakukan kekejamna fisik terhadap orang lain, (5) melakukan kekejaman fisik terhadap hewan, (6) mencuri sambil mengkonfrontasi korban (missalnya pencopetan, perampokan bersenjata), (7) memaksa seseorang untuk melakukan aktivitas seksual, atau destruction of property (melakukan pengrusakan barang), misalnya: (8) melakukan pembakaran secara sengaja dengan tujuan untuk menghasilkan kerusakan yang serius, (9) melakukan pengrusakan barang atau benda secara sengaja. Atau deceitfulness or theft (melakukan penipuan atau pencurian), misalnya: (10) masuk secara paksa ke dalam rumah, bnagunan atau mobil, (11) sering berbohong untuk memperoleh barang atau jasa atau untuk menghindari kewajiban (misalnya mengutil namun tanpa merusak), (12) mencuri tanpa konfrontasi. Atau serious violations of rules (melakukan pelanggaran aturan yang serius), misalnya: (13) sering keluar rumah pada malam hari meskipun dilarang, yang dimulai pada usia 13 tahun, (14) melarikan diri dari rumah pada malam ahri setidaknya 2 kali selama tinggal di rumah orang tua atau orang tua asuh (atau satu kali tanpa kembali ke rumah untuk jangka waktu lama), (15) sering bolos dari sekolah yang di mulai sebelum usia 13 tahun.

Ada tiga faktor penyebab gangguan tingkah laku pada anak yaitu:

1. Faktor biologis yaitu temperamen yang merupakan gaya karakteristik seseorang dalam melakukan pendekatan dan bereaksi terhadap orang dan situasi dilingkungannya.

2. Faktor individual yaitu regulasi diri (selfregulation) yang kurang terbentuk sejak dini, regulasi emosi yang buruk sehingga anak tidak dapat mengembangkan strategi coping (strategi dalam mengatasi masalah) yang baik untuk mengatasi emosi negatifnya dan mengatur emosinya, kurang berkembangnya pemahaman moral dan empati, kognisi sosial anak yang berkembang dengan buruk, dan penggunaan obat-obatan terlarang.

3. Faktor keluarga yaitu perilaku antisosial orang tua mereka, strategi disiplin orang tua yang tidak efektif dan tidak konsisten serta lemahnya pengawasan orang tua, kurangnya komunikasi dan kasih sayang orang tua, attachment (kelekatan orang tua dan anak), masalah dalam rumah tangga, psikopatologi yang dialami orang tua, pola asuh yang tidak konsisten dan kurangnya pengawasan.

\section{DAFTAR RUJUKAN}

Achmad Mubarok, 2000. Jiwa dalam AlQur'an, Jakarta: Paramadina

American Psychiatric Association, 2000. Diagnostic and Statistical Manual of Mental Disorder $\quad\left(4^{\text {th }}\right.$ ed) Text Revision Washington, DC: American Psychiatric Association

Charles Wenar dan Patricia Kerig,.t.t. Development Psychopathology from 
Infancy Through Adolescence, edisi ke-5, Linda De Clerg, 1994. Tingkah Laku Abnormal, New York : McGraw-Hill dari Sudut Padang Perkembangan, Jakarta: Diane E. Papalia dan Sally Wendkos Mubarok, Grasindo 1995. Human Developmenr USA: McGraw-Hill, 